ofitseriv-prykordonnykiv u protsesi vyvchennia humanitarnykh dystsyplyn. Kandydat nauk. Nats. akad. Derzh. prykordonnoi sluzhby Ukrainy im. B. Khmelnytskoho. Khmelnytskyi.

5. Poliuha, V. A., 2006. Dynamika tsinnisnykh oriientatsii viiskovosluzhbovtsiv strokovoi sluzhby. Kandydat nauk. Kyiv. nats. un-t im. T. Shevchenka. Kyiv.

5. Martyniuk, V. M., 2006. Tsinnisni oriientatsii viiskovosluzhbovtsiv zbroinykh syl Ukrainy (sotsialno-filosofskyi analiz). Kandydat nauk.
Kharkivskyi un-t Povitrianykh Syl im. Ivana Kozheduba. Kharkiv.

6. Matviichuk, V. P., 2009. Pedahohichna tekhnolohiia formuvannia tsinnisnykh oriientatsii u maibutnikh ofitseriv-prykordonnykiv. Kandydat nauk. Nats. akad. Derzh. prykordonnoi sluzhby Ukrainy im. B. Khmelnytskoho. Khmelnytskyi.

7. Solovev, S. S., 1996. Transformatsyia tsennostei voennoi sluzhby. Sotsyolohycheskye yssledovanyia, $9,160 \mathrm{~s}$.

УДК 377/378:656.7]:37.091.33

https://doi.org/10.32835/2223-5752.2018.16.55-61.

\title{
ПРОБЛЕМНЕ НАВЧАННЯ В ПРОФЕСІЙНІЙ ПІДГОТОВЦІ ДИСПЕТЧЕРІВ УПРАВЛІННЯ ПОВІТРЯНИМ РУХОМ
}

Оксана Данилко,

кандидат педагогічних наук,

доиент кафедри інформаційних технологій та обслуговування повітряного руху

Льотної академії Національного авіаційного університету

ORCID: 0000-0002-7942-8012

e-mail:monyasolnce@gmail.com

\section{Катерина Суркова,}

кандидат педагогічних наук, доцент,

доцент кафедри інформаційних технологій та обслуговування повітряного руху

Льотної академії Національного авіаційного університету

ORCID: 0000-0002-1388-7611

e-mail:eskirua@gmail.com

\section{КЛЮЧОВІ СЛОВА:}

Проблемне навчання, професійна діяльність та підготовка диспетчерів управління повітряним рухом, рівні навчальних досягнень, практичні завдання проблемного типу
Реферат

У статті проаналізовано наукові досягнення теорії та практики проблемного навчання до професійної підготовки диспетчерів управління повітряного руху. Актуальність даної теми обумовлюється недостатньою адаптацією та розробленістю деяких положень проблемного навчання відносно підготовки майбутніх диспетчерів управління повітряного руху як фахівців операторського профілю. Розглянуто психологічні основи проблемного навчання та описано фактори, що впливають на складність проблемного завдання. Подано структуру організації проблемного навчання в процесі теоретичної підготовки авіаційних операторів. Описано групи методів навчання та професійної підготовки авіаційних фахівців. Розглянуто деякі професійноорієнтовані дисципліни, які є основою для якісного виконання професійних завдань при обслуговуванні повітряного руху та які входять в систему професійної підготовки диспетчерів управління повітряного руху, складовими якої є теоретична (дотренажерна) та тренажерна підготовка. На основі цього встановлено, що на даний час недостатньо використовуються наукові досягнення з проблемного навчання, що потребує доопрацювання. Виділено чотири рівні навчальних досягнень курсантів в процесі розв'язання проблемних ситуацій: низький, середній, достатній і високий. Подано компоненти проблемних завдань, такі як: умови проблемної ситуації, проблема, розв'язок проблеми, критерії оцінювання прийнятих рішень. Акцентовано увагу на перевагах проблемного навчання як можливостях для розвитку професійно-важливих якостей майбутніх авіадиспетчерів, а саме: уваги, пам'яті, спостережливості, активізації мислення, активізації пізнавальної діяльності, самостійності, відповідальності, критичності і самокритичності, ініціативності, нестандартності мислення, обережності і рішучості тощо. Показано, що якісне застосування отриманих професійних знань і грамотне рішення виробничих завдань в різних умовах діяльності залежить від використання завдань проблемного типу в професійній підготовці диспетчерів управління повітряного руху. Такі завдання забезпечують формування у курсантів достатнього і високого рівнів навчальних досягнень, які відповідають ступеню застосування і творчості в майбутній професійній діяльності. 
Постановка проблеми. Диспетчерська робота $\epsilon$ одним 3 найбільш складних i відповідальних видів діяльності, вона пред'являє високі вимоги до людини-оператора. Для цієї роботи характерна висока ймовірність виникнення екстремальних ситуацій, що вимагають швидкого й грамотного прийняття рішень. Для представників цієї професії особливо важливі такі якості, як швидкість сприйняття і оцінки інформації, що надходить, рівень концентрації та розподілу уваги, стійкість емоційно-вольової сфери, швидкість орієнтування і прогнозування розвитку ситуації, особливості просторового мислення. Мета навчання диспетчерів управління повітряним рухом (УПР) полягає в оволодінні майбутніми диспетчерами знаннями, навичками і уміннями, необхідними для виконання своїх професійних обов'язків безпечно і ефективно. Диспетчер повинен розуміти і визначати пріоритети відповідної інформації, а також вміти планувати майбутню діяльність, своєчасно приймати необхідні рішення, виконувати їх і забезпечувати їх дотримання. Із зростанням інтенсивності повітряного руху, появою високошвидкісних повітряних суден (ПС) підвищується завантаженість авіадиспетчера i збільшується ймовірність прийняття ним помилкових рішень або несвоєчасного виявлення потенційно конфліктної ситуації. При обслуговуванні сукупності ПС, складність управління, пов'язана 3 виникненням небезпечних ситуацій, зростає в декілька разів. Однією з причин виникнення помилкових дій авіадиспетчерів $€$ недостатній рівень професійної підготовки, тому дослідження, пов'язані 3 цім напрямом мають актуальний характер і можуть значною мірою сприяти підвищенню рівня безпеки польотів.

Аналіз наукових праць. Теорія проблемного навчаннямаєвласнийпонятійнийапарат,якийдетально розроблений в дослідженнях Т. В. Кудрявцева, I. Я. Лернера, А. М. Матюшкина, М. І. Махмутова, В. Оконя та інших вчених. У цих роботах було виділено ряд основних понять цієї теорії: проблемна ситуація, навчальна проблема, проблемне завдання, проблемне питання, спосіб вирішення проблемного завдання, рівень проблемного навчання та ін. Роботи P.М. Макарова значною мірою посприяли розвитку теорії та практики проблемного навчання в авіаційній педагогіці стосовно підготовки льотного складу. В рамках нашого дослідження встановлено, що недостатньо адаптовані та розвинуті деякі положення проблемного навчання щодо підготовки майбутніх диспетчерів УПР, виникає потреба розробки моделі проблемного завдання, яке б враховувало особливості професійної підготовки авіадиспетчерів як фахівців операторського профілю, такої моделі, яка дозволяє змінювати складність проблемного завдання в залежності від рівня навчальних досягнень курсантів.

Метою статті $\epsilon$ адаптація наукових пояснень теорії та практики проблемного навчання до професійної підготовки диспетчерів УПР.
Виклад основного матеріалу. На диспетчера УПР впливає безліч негативних чинників: інформаційна завантаженість, висока щільність, різноманіття i швидкоплинність потоку одержуваної інформації, висока відповідальність за прийняте рішення, строгий ліміт $\mathrm{i}$ дефіцит часу. Тому професійна підготовка таких фахівців $є$ важливим процесом $\mathrm{i}$ реалізується сукупністю дисциплін, які дають змогу шляхом взаємозв'язку і єдиною функціональною спрямованістю досягти необхідного результату сформованості й надійності умінь і навичок УПР в різних умовах діяльності.

В процесі навчання диспетчерів УПР використовуються різні методи навчання. Аудиторне навчання принципам i теорії управління ПС за допомогою відповідних традиційних академічних методів не можуть в повній мірі забезпечити якісну підготовку фахівців операторського профілю, тому необхідно застосовувати більш активні методи навчання. До таких методів належать проблемнопошукові методи навчання, які передбачають застосування проблемних завдань. Особливості професійної діяльності диспетчерів УПР та, зокрема, велика ймовірність виникнення проблемних ситуацій, обумовлюють необхідність застосування методів проблемного навчання. Змістовне наповнення професійної підготовки повинно конструюватися таким чином, щоб забезпечити не тільки ефективну передачу навчальної інформації, а й сформувати у курсантів здатність найбільш ефективно використовувати цю інформацію в своїй практичній діяльності. При цьому головною вимогою $\epsilon$ моделювання реальних професійних ситуацій, яке повинно грунтуватися на положеннях теорії проблемного навчання по розробці ситуаційних завдань проблемного типу.

Ряд відомих дослідників, серед яких i А. Матюшкін (2009), розробили психологічні основи проблемного навчання в його різних модифікаціях. Суть його полягає в наступному. Перед учнями ставиться проблема, пізнавальне завдання, і учні (при безпосередній участі вчителя чи самостійно) досліджують шляхи і способи іiі рішення. Вони будують гіпотезу, намічають і обговорюють способи перевірки іiі істинності, аргументують, проводять експерименти, спостереження, аналізують їх результати, міркують, доводять.

До психологічної структури проблемної ситуації учений (2009) відносить такі компоненти: пізнавальну потребу, яка спонукає студента до інтелектуальної діяльності; знання або спосіб дії, які студент прагне здобути, а також інтелектуальні можливості студента (досвід пошукової діяльності та творчі здібності).

Складність проблемного завдання, на думку I. Лернера (1970), зумовлена трьома факторами: складом умови: чим більше даних, які потрібно враховувати при вирішенні завдання, тим воно 
складніше; дистанцією між постановкою завдання і відповіддю на нього, тобто числом суджень, логічних ланок, необхідних для вирішення завдання (провідний фактор складності); складом рішення, тобто числом висновків, які можна зробити в результаті рішення завдання. Подальший розвиток теорії проблемного навчання в руслі професійної підготовки авіаційних операторів знайшло відображення в дослідженнях Р. Макарова (1997, 2005). Структура організації проблемного навчання в процесі спеціальної теоретичної підготовки представлена на рис.1.

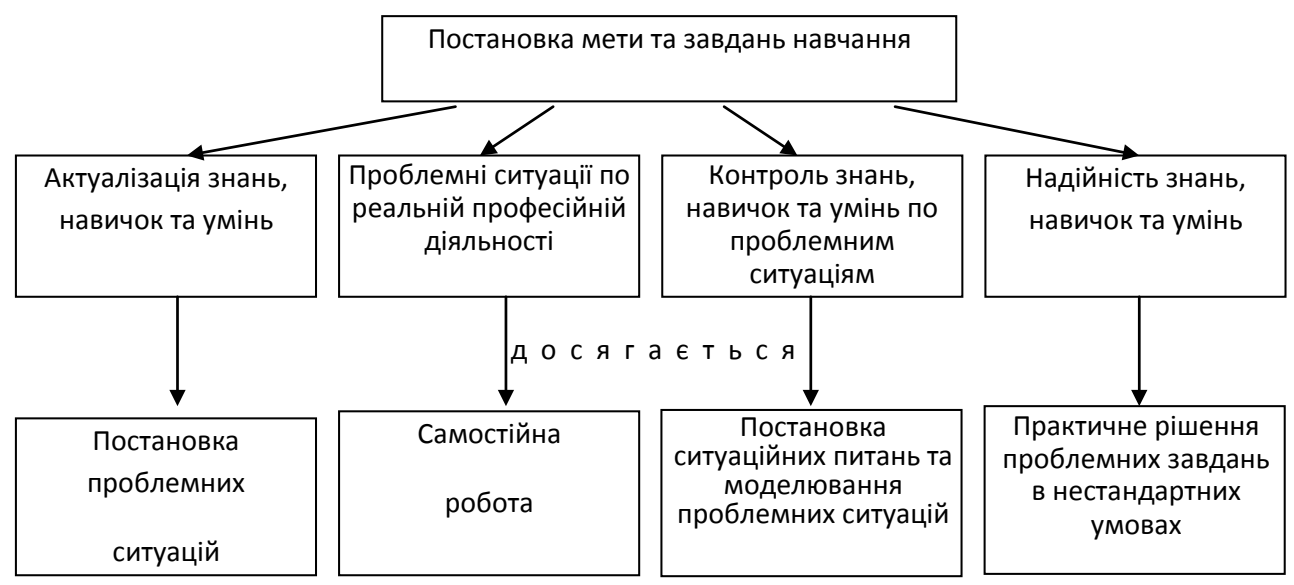

Рис. 1 Структура організації проблемного навчання в процесі теоретичної підготовки (Р. Макаров)

Р. Макаров (1997) виділяє такі групи навчання має особливе значення для методів навчання авіаційних фахівців: формування необхідного рівня надійності репродуктивні методи навчання, програмовано- пілота i авіадиспетчера, для цього потрібне алгоритмізовані методи і прийоми навчання, використання всіх трьох груп методів проблемно-пошукові методи навчання. На відповідно до етапів навчання (рис. 2). думку вченого, правильний вибір методів

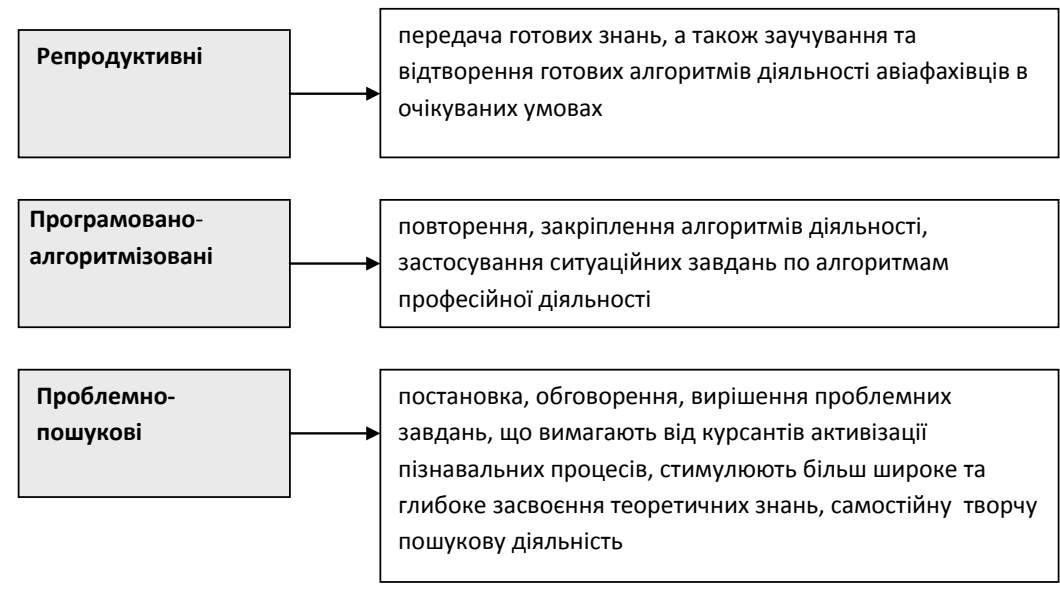

\section{Рис. 2. Групи методів професійної підготовки авіафахівців}

Щоб стати авіадиспетчером, необхідно успішно пройти курс початкової підготовки диспетчерів УПР, до складу якої входять базова і рейтингова підготовки. Етап базової підготовки входить у програму навчального курсу процесу здобуття освітньо-кваліфікаційного рівня «бакалавр» напряму підготовки «Аеронавігація», навчання відбувається в авіаційних вищих 
навчальних закладах (ВН3). Рейтингова підготовка здійснюється в Навчальносертифікаційному центрі Украероруху.

Крім загальноосвітніх дисциплін, таких, як вища математика, фізика та інші, в навчальні програми авіаційних ВНЗ включені спеціальні дисципліни курсу базової підготовки: вступ до курсу, повітряне право, організація повітряного руху, авіаційна метеорологія, повітряна навігація, повітряні судна, людський фактор, обладнання та технічні засоби для обслуговування повітряного руху (ОПР) тощо. Розглянемо деякі професійноорієнтовані дисципліни, які $\epsilon$ основою для якісного виконання професійних завдань при ОПР.

У ході аналізу навчальної програми дисципліни «Радіотелефонія» встановлено, що на базі сучасних методів аналізу діяльності людини-оператора в аеронавігаційній системі розкривається зміст i вимоги до процесів УПР методом мовного спілкування і ведення радіозв'язку авіаційною англійською мовою. Оволодіння даною дисципліною передбачає формування основних знань, умінь і навичок 3 використанням правил і фразеології радіообміну між органами ОПР та екіпажами ПС англійською мовою.

Дисципліна «Управління повітряним рухом» формує основні знання, уміння i навички, необхідні курсантам для проходження технологічної практики на диспетчерських тренажерах та на авіаційних підприємствах, для адаптації на робочому місці у виробничих умовах, під час стажування, для подальшої роботи в якості диспетчера служби руху. Засвоєння змісту дисципліни полягає в тому, щоб на базі сучасних методів опису та формалізації діяльності людини-оператора розкрити суть процесів безпосереднього управління повітряним рухом в різних зонах ОПР і на аеродромі із застосуванням діючих в авіації правил польотів і правил ОПР.

Дисципліна «Професійна англійська мова (авіаційна)» спрямована на вивчення лексичного матеріалу 3 професійної англійської мови, авіаційної термінології, використовуваної в рамках професійної діяльності при ОПР в нестандартних ситуаціях. Обробка навчального матеріалу авіаційної спрямованості шляхом перекладу, аудіювання, зіставлення приводить до закріплення i поглиблення набутих знань i, як досягнення кінцевої мети,- до можливості вільного спілкування в рамках обраної професії.
Порядок вивчення матеріалу із зазначених дисциплін i розподіл навчального часу за темами повинні забезпечити своєчасну та якісну підготовку курсантів до виконання вправ на диспетчерських тренажерах i проходженню виробничих практик у структурах ОПР

Важливим компонентом професійної підготовки майбутніх авіадиспетчерів $\epsilon$ тренажерна підготовка. Саме цей вид підготовки акумулює всі отримані знання 3 професійноорієнтованих дисциплін і виявляє прогалини в навчальних досягненнях. У процесі тренажерної підготовки відбувається закріплення навичок ведення радіообміну в максимально наближених до реальної професійної діяльності умовах, проявляється зв'язок між професійними навичками УПР і мовними навичками курсанта, перевіряється їх міцність i надійність у стандартних та екстремальних умовах.

Дисципліни «Радіотелефонія», «Управління повітряним рухом», «Професійна англійська мова (авіаційна)», «Практична підготовка на диспетчерських тренажерах» сприяють формуванню професійних знань, навичок, умінь з УПР. Вивчення зазначених дисциплін відбувається в ході теоретичного та тренажерного етапів професійної підготовки. Зрозуміло, що зазначені дисципліни не є відокремленими від інших дисциплін професійного спрямування, вони безпосередньо спираються на них та існують в єдиній системі професійної підготовки. Наразі на заняттях 3 дисциплін професійної спрямованості на дотренажерному етапі професійної підготовки застосовуються різні методи навчання, причому, в більшій мірі застосовуються традиційні методи, спрямовані на передачу готових знань, а також заучування та відтворення готових алгоритмів діяльності диспетчерів УПР. Встановлено, що в результаті застосування різних типів практичних завдань можуть бути отримані відповідні рівні навчальних досягнень (таблиця 1.). Матеріал, представлений в таблиці, узагальнено за результатами досліджень В. Беспалько (2006) та Р. Макарова $(1997,2005)$.

Репродуктивні завдання передбачають володіння знаннями-знайомством, тобто здатністю курсантів упізнавати об'єкти i процеси, розпізнавати й співвідносити їх (розпізнавання, запам'ятовування понять i алгоритмів професійної діяльності, розрахованих на очікувані умови експлуатації). 
Рівні навчальних досягнень

Таблиця 1.

\begin{tabular}{|c|c|c|c|}
\hline $\begin{array}{c}\text { Рівні } \\
\text { досягнень }\end{array}$ & $\begin{array}{c}\text { Ступені } \\
\text { досягнень }\end{array}$ & Навчальна діяльність & $\begin{array}{l}\text { Практичні } \\
\text { завдання }\end{array}$ \\
\hline 1.Низький & $\begin{array}{l}\text { розпізнавання, } \\
\text { запам'ятовування } \\
\text { (розпізнавання) }\end{array}$ & $\begin{array}{l}\text { фрагментарність знань } \\
\text { дозволяє курсанту сприйняти та } \\
\text { запам’ятати, щоб мати початкові } \\
\text { уявлення про предмет вивчення }\end{array}$ & $\begin{array}{l}\text { Репродуктивні } \\
\text { завдання }\end{array}$ \\
\hline 2.Середній & $\begin{array}{l}\text { розпізнавання, } \\
\text { запам’ятовування, } \\
\text { розуміння, } \\
\text { елементарні } \\
\text { навички та вміння в } \\
\text { стандартних умовах } \\
\text { (відтворення) }\end{array}$ & $\begin{array}{l}\text { курсант відтворює основний } \\
\text { навчальний матеріал, здатний } \\
\text { виконувати завдання за зразком, } \\
\text { володіє елементарними навичками } \\
\text { та вміннями при розв'язанні } \\
\text { типових задач }\end{array}$ & $\begin{array}{l}\text { Репродуктивно- } \\
\text { алгоритмізовані } \\
\text { завдання }\end{array}$ \\
\hline 3.Достатній & $\begin{array}{l}\text { розпізнавання, } \\
\text { запам'ятовування, } \\
\text { розуміння, навички } \\
\text { та вміння в } \\
\text { стандартних умовах } \\
\text { (застосування) }\end{array}$ & $\begin{array}{l}\text { знання істотних ознак понять, } \\
\text { явищ, зв’язків між ними } \\
\text { дозволяє курсанту пояснити } \\
\text { основні закономірності, } \\
\text { самостійно застосовувати } \\
\text { знання в стандартних ситуаціях; } \\
\text { курсант володіє розумовими } \\
\text { операціями (аналіз, абстрагування, } \\
\text { узагальнення тощо), вміє робити } \\
\text { висновки, виправляти допущені } \\
\text { помилки }\end{array}$ & $\begin{array}{l}\text { Проблемно- } \\
\text { алгоритмізовані } \\
\text { завдання }\end{array}$ \\
\hline 4.Високий & $\begin{array}{l}\text { розпізнавання, } \\
\text { запам’ятовування, } \\
\text { розуміння, навички } \\
\text { та вміння в різних } \\
\text { умовах діяльності } \\
\text { (творчість) }\end{array}$ & $\begin{array}{l}\text { глибокі, міцні, узагальнені, } \\
\text { системні знання дозволяють } \\
\text { курсанту самостійно оцінювати } \\
\text { та вирішувати складні професійні } \\
\text { задачі в екстремальних умовах } \\
\text { діяльності }\end{array}$ & $\begin{array}{l}\text { Проблемно- } \\
\text { пошукові } \\
\text { завдання }\end{array}$ \\
\hline
\end{tabular}

Репродуктивно-алгоритмізовані завдання передбачають володіння знаннями-копією, тобто здатністю відтворити (повторити) інформацію, операції, дії, вирішити задачу за зразком (відтворення типових дій згідно 3 алгоритмом). Проблемно-алгоритмізовані завдання передбачають застосування знань у практичній сфері для вирішення завдань у подібних ситуаціях на основі самостійного використання засвоєних знань-копій (самостійно 3 певними прийомами (алгоритмами) міркувань і дій досягти поставленої мети у вирішені стандартної ситуаціі). Проблемнопошукові завдання передбачають застосування курсантами засвоєної інформації на основі перенесення умінь і навичок в нові обставини, рішення творчих завдань, вироблення нових прийомів і способів їх вирішення (самостійно оцінювати, прогнозувати, вирішувати складні завдання в екстремальних умовах діяльності).

Проблемненавчання майбутніх авіадиспетчерів має бути максимально наближеним до вирішення реальних професійних завдань i складатися iз таких етапів: формулювання проблемного завдання; індивідуальне або групове вирішення проблеми курсантами; перевірка прийнятих рішень; застосування отриманих знань у подальшій теоретичній та практичній підготовці майбутніх авіадиспетчерів.

У ході дослідження встановлено, що проблемні завдання повинні складатися з таких компонентів: умови проблемної ситуації, проблема, розв'язок проблеми, критерії оцінювання прийнятих рішень. При цьому змістове наповнення таких компонентів повинно включати особливості, притаманні 
професійній діяльності диспетчерів УПР, а саме: управління значною кількістю об'єктів та параметрів; сприймання, переробка великого обсягу інформації; висока точність дій і швидкість прийняття рішення, висока відповідальність за дії та прийняті рішення; емоційні та інтелектуальні перевантаження тощо. Переваги проблемного навчання очевидні. Це, насамперед, великі можливості для розвитку професійно-важливих якостей майбутніх авіадиспетчерів, а саме: уваги, пам'яті, спостережливості, активізації мислення, активізації пізнавальної діяльності, самостійності, відповідальності, критичності й самокритичності, ініціативності, нестандартності мислення, обережності і рішучості тощо. Крім того, що дуже важливо, проблемне навчання забезпечує міцність набутих знань, умінь та навичок, бо вони здобуваються самостійною діяльністю, в активному пошуку розв'язку проблемних ситуацій.

Висновок. Таким чином, якісне застосування отриманих професійних знань і грамотне рішення виробничих завдань в різних умовах діяльності залежить від використання завдань проблемного типу в професійній підготовці диспетчерів УПР. Такі завдання забезпечують формування в курсантів достатнього i високого рівнів навчальних досягнень, що відповідають ступеню застосування і творчості в майбутній професійній діяльності. Подальшими напрямами дослідження вважаємо детальний опис та обгрунтування, як теоретичне, так і експериментальне, кожного компонента проблемного завдання, встановлення взаємозв'язків між компонентами проблемного завдання, встановлення та регулювання рівнів складності завдань залежно від рівня навчальних досягнень курсантів.

\section{Література}

1. Беспалько, В. П., 2006. Параметры и критерии диагностичной цели. Школьные технологии, 1, с. 118-128.

2. Лернер, И. Я., 1970. Факторы сложности познавательных задач. Hовые исследования в педагогических науках, 1, с.8692.

3. Макаров, Р. Н., Герасименко, Л. В. 1997. Теория и практика конструирования цчелевых моделей операторов особо сложных систем управления. М.: МАКЧАК.

4. Макаров, Р. Н., Неделько, С. Н., Бамбуркин, А. П., Григорецкий, В. А. 2005. Авиаџионная педагогика. Кировоград: МНАПЧАК, ГЛАУ.

5. Матюшкин, А. М. 2009. Психология мышиления. Мышление как разрешение проблемных ситуаций. М.: КДУ.

\section{KEY WORDS:}

Problem learning, professional training of aviation specialists, air traffic controllers, educational achievement levels, practical tasks of problem type

\section{Abstract}

\section{The problem-based learning in the training of air traffic controllers}

\author{
Oksana Danylko, \\ Candidate of Pedagogical Sciences, \\ Associate Professor of Department of Information \\ Technologies and Air Traffic Control \\ Flight Academy of National Aviation University \\ Kateryna Surkova, \\ Candidate of Pedagogical Sciences, Associate Professor, \\ Associate Professor of Department of Information \\ Technologies and Air Traffic Control \\ Flight Academy of National Aviation University
}


at present, and require improvement. There are four levels of scientific achievements of students in theprocess of solving problem situations: low, medium, sufficient and high. We submit such components of problem situations as: conditions of a problem situation, a problem, problem solving, criteria for decisions evaluating. The preferences of the problem-based learning are emphasized as opportunities for developing the professionally important qualities of future air traffic controllers, such as: attention, memory, observation, activation of thinking, enhancing cognitive activity, autonomy, responsibility, criticality and self-criticism, initiative, out-of-routine thinking, caution and determination and etc. It is shown that the high quality knowledge management gained and the competent solution of production problems in different activity conditions depends on the usage of problem-type tasks in the professional training of air traffic controllers. Such tasks ensure the formation of students' educational achievements of sufficient and high level, which correspond to the degree of appliance and creativity in future professional activities.

\title{
References
}

1. Bespalko, V.P., 2006. Parametryi i kriterii diagnostichnoy tseli. Shkolnyie tehnologii, 1, s. 118128.

2. Lerner, I.Ya., 1970. Faktoryi slozhnosti poznavatelnyih zadach. Novyie issledovaniya $v$ pedagogicheskih naukah, 1, s.86-92.

3. Makarov, R.N., Gerasimenko, L.V. 1997. Teoriya $i$ praktika konstruirovaniya tselevyih modeley operatorov osobo slozhnyih sistem upravleniya. M.: MAKChAK.

4. Makarov, R.N., Nedelko, S.N., Bamburkin, A.P., Grigoretskiy, V.A. 2005. Aviatsionnaya pedagogika. Kirovograd: MNAPChAK, GLAU.

5. Matyushkin, A.M. 2009. Psihologiya myishleniya. Myishlenie kak razreshenie problemnyih situatsiy. M.: KDU.

УДК 377.091.113-05:[008:005.57

https://doi.org/10.32835/2223-5752.2018.16.61-68.

\section{РОЗВИТОК КОМУНІКАТИВНОЇ КУЛЬТУРИ КЕРІВНИКІВ ЗАКЛАДІВ ПРОФЕСІЙНОЇ ОСВІТИ В СУЧАСНИХ УМОВАХ}

\author{
Олена Пищик, \\ заступник директора з навчально-виробничої роботи \\ ДПТНЗ «Чернігівський иентр професійно-технічної освіти» \\ ORCID: 0000-0001-9193-6645 \\ e-mail:pishik_elena@ukr.net
}

КЛЮЧОВІ СЛОВА:

комунікативна культура, керівники закладів професійної (професійно-технічної) освіти, компетентність, комунікативна компетентність, заклад професійної (професійно-технічної) освіти, управління

\section{Реферат}

У статті розглядаються прикладні аспекти розвитку комунікативної культури сучасних керівників закладів професійної (професійно-технічної) освіти в структурі їх управлінської діяльності. Аналізується зміст комунікативної культури керівників закладів професійної (професійно-технічної) освіти та розуміння феномену комунікативної компетенції як базової складової комунікативної культури керівників закладів професійної (професійно-технічної) освіти. Розглянуто суть поняття «комунікативна культура». Представлено результати дослідження, що проводилося 3 метою вивчення стану комунікативної культури, інтересів, потреб та готовності керівників закладів професійної (професійно-технічної) освіти до розвитку комунікативної культури.

Основна увага у статті приділена діагностиці комунікативної компетенції керівників закладів професійної (професійно-технічної) освіти. Визначено, що процес удосконалення комунікативної компетенції пов'язаний з розвитком особистості. Сучасний керівник закладу освіти повинен володіти не тільки знаннями, навичками та вміннями у своїй галузі, але також мати добре розвинені творчі, комунікативні та інші здібності. Розвиток комунікативної культури керівників закладів професійної (професійно-технічної) освіти має стимулювати керівників-лідерів до отримання психологічних знань, прагнення до самовдосконалення, усвідомлення необхідності розвитку власної комунікативної культури. 